\title{
Design of remotely operated vehicle as installer tools of tidal turbine and seismograph under water
}

\author{
Muhammad Sulthan Mazaya \\ MBI Amanatul Ummah, Indonesia
}

\begin{tabular}{l} 
Article Info \\
\hline Article history: \\
Received Jan 6, 2019 \\
Revised Mar 21, 2019 \\
Accepted Mar 3, 2019 \\
\hline
\end{tabular}

Keywords:

Design

Microcontroller

Remotely operated vehicle

Under water

\begin{abstract}
Tidal turbines and seismographs constitute instruments that can be used as an earthquake detector that lead to tsunamis. As an early detection instrument for tsunami disaster, tidal turbine and seismograph are generally placed under the surface of water. The design objective in this study is designing a Remotely Operated Vehicle (ROV) which can be used as a tool for tidal turbine and seismograph installation. The design method applied in this study is designing prototype by following the product research and development procedures. Making control systems has three stages, namely: software design, hardware manufacture, and software and hardware integration. The made software includes the ROV motion control program through the control of Anduino Nano R2 ATMega microcontroller with programming that uses $\mathrm{C}$-Basic language. The design findings show that the designed ROV can be used effectively to simulate the installation of tidal turbine and seismograph under the surface of water in 2 meters at depth with 15 minutes of installation time in undulating water.
\end{abstract}

Copyright $@ 2019$ Institute of Advanced Engineering and Science. All rights reserved.

\section{Corresponding Author:}

Muhammad Sulthan Mazaya,

MBI Amanatul Ummah,

Jl. Tirtowening No. 2, Mojokerto, Indonesia.

Email: msulthanmazaya@gmail.com

\section{INTRODUCTION}

Indonesia is regarded to be a country with highly tendency to disasters [1-2]. During the years of 1629-2014, Indonesia suffers from 174 tsunamis in which 60 percent of them occurred in Eastern Indonesia [3]. Generally, Tsunami disaster begins with an earthquake which results in waves in the deep water which then spread to shallow water. When coming to the shallow water, tsunami will undergo a wave transformation. Tsunami is not seen to be a single wave. However, it is generally a wave in the deep ocean with 0.5 meter in height. When approaching the coast, the wave height can reach 15 meters or even greater. Tsunami has a very large force because of the huge volume of water and its fast speed. Tsunami may approaches the coast at around $48 \mathrm{~km} /$ hour with its millions tons in strength [4]. This big wave power will cause serious disasters to the coastal communities.

The UNDP of United Nations stated that awareness to disaster would minimize the adverse impacts of disaster through effective prevention, rehabilitation and on time aid delivery [3]. Natural disasters can be mitigated by preventive efforts [5]. In order to reduce the impact of earthquake, it requires readiness to face the earthquake as it can occur at any time [6]. In this regard, it is necessary to build seismograph installation under the water to gather information so that people have enough preparations to face the earthquake. Whether to gave it in the term of warnings to the shore areas or to analyse the effects of the seaquakes [7]. The installation can be assisted by ROV (Remotely Operated Vehicle) that functions to install seismographs in the sea so that the installation is not done in a conventional manner.

The installation of tidal turbine and seismograph can be done by a robot that works under the surface of water, ROV is basically a tethered underwater robot [8], typically tethered to a monitoring dock to 
obtain power and transmitting data [9], which may allow it to work under the installation assisted by it pilot in the surface. The advancement of robot technology cannot be separated from the use of microcontroller chips as a control center of robots [10], including the use of robot below the surface of water.

The utilization of underwater robot technology still has less attention. Nowadays, there are many underwater activities carried out in conventional ways such as underwater observation, underwater survey of natural resources, monitoring dam fractures, searching for natural disaster victims or sinking ships. Underwater activities have several risks, namely: water contaminated by toxic waste, areas beyond humans coverage, hydrostatic pressure in the body of divers, limited oxygen, and high dangerous risk due to attacks of wild animals, and so forth. Therefore, to deal with the various limitations of human activity under the surface of water, it is imperative to design a robot that can move freely in water to help human tasks [11].

This research is triggered and departs from the weaknesses of previous studies. The research by Gitakarma, et. al. (2014) entitled "Underwater Survey Aid Using AMOBA, ROV-Based Robots" stated that the underwater robot is controlled by PS2 remote connected with a 15-meter cable to the MCS-51 microcontroller as the robot's control center. Eight water pumps are installed on the robot as actuators which serve to maneuver in water [12]. This device, however, is inefficient, for it uses too many water pumps as the main driver of the robot.

Another study by Nugraha, et. al. (2018) entitled "Designing ROV (Remotely Operated Vehicle) Based on Arduino Uno R3". This ROV is run by a system that is controlled through a controller device. Underwater video camera system is installed in ROV that is controlled from the surface of the water. The control system and ROV are connected with data transmission in the form of cable. The robot frame is made of PVC pipes [13]. Based on the author's experience, the use of PVC has a difficulty in designing construction and reconstruction of the robot's skeleton.

In this study, ROV is designed efficiently in using water pumps, with its ability to float, stay, and sink in water stably. The robot frame uses aluminum extrusion to facilitate the reconstruction of robot design. The designed ROV operation has a grip function, which can be applied to assist the installation of tidal turbine and seismograph in water.

\section{Material and Design Method \\ 2.1. Material}

Here are the materials used to design ROV:

a. Bilge Pump Motor $1100 \mathrm{GPH}$

b. Arduino Nano

c. Aluminium Profile

d. T-Nut

e. Enclosure Waterproff

f. Acrylic 5mm and Cutting $\mathrm{P}$

g. Servo Waterproff

h. 3D Print Bilge Pump

i. 3D Print Propeller

j. 3D Print Propeller Protector

k. Camera

1. Cable $11 \mathrm{AWG}$

m. Monitor 7"

n. Joystik PS

\subsection{Design Method}

The design of ROV applies Research and Development (R\&D) method. The method of R\&D is done to make certain products and test the effectiveness of the products [14]. As for the development stage, ROV is designed through the modification of Gall, et. al. (1996) model that covers the following stages: research and information collecting, planning, developing preliminary form of product, preliminary field testing, main product revision, operational field testing, and final product revision [15]. Research and development shown is Figure 1.

Making control system is done through three stages, namely designing system flowchart, making hardware, and integrating/combining software and hardware. The made software includes the ROV motion control program through the control of the Anduino Nano R2 ATMega microcontroller with C basic language. The designing of ROV was performed by ANDROMEDA team that includes 10 students of class $\mathrm{X}$ and XI at the MBI of Amanatul Ummah Mojokerto, in which the author is part of ANDROMEDA team. The designed ROV is named Lelebot 1.0. 


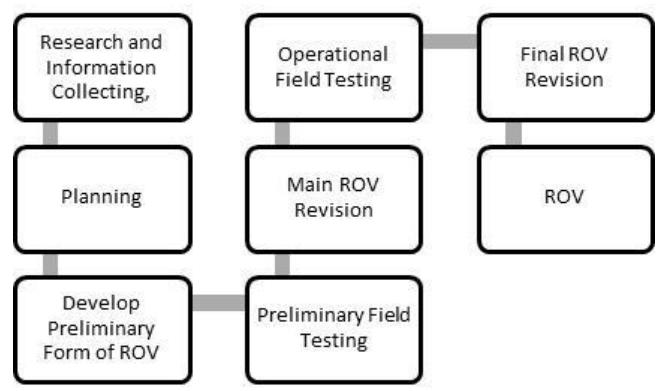

Figure 1. Research and development

\section{RESULT AND DISCUSSION}

The design of ROV Lelebot 1.0 follows the Interconnection System Diagram as presented in Figure 2. While the preparation of hardware follows the flow diagram as presented in Figure 3.

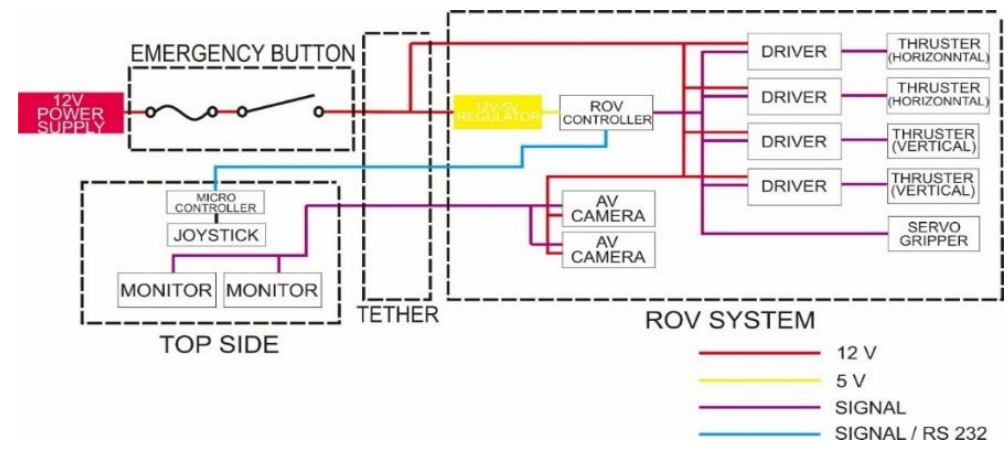

Figure 2. System interconnection diagram

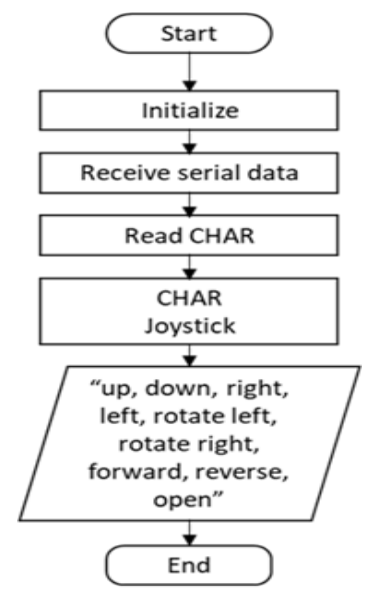

Figure 3. Hardware design flow chart

\subsection{Frame Design}

Basically, the frame of ROV Lelebot 1.0 is built using aluminum extrusion $20 \times 20 \mathrm{~cm}$. Material selection is done to make a compact, lightweight, and long-durable design. The use of aluminum extrusion will facilitate the configuration of gripper position, camera and motor. Although the nature of aluminum extrusion is different from PVC, that aluminum does not float in water, the design of the floating system of the ROV Lelebot 1.0 was done with an additional installation of 2 bottles that function to stabilize the ROV Lelebot 1.0 design.

Design of remotely operated vehicle as installer tools of tidal turbine and... (Muhammad Sulthan Mazaya) 
The design of ROV Lelebot 1.0 uses SolidWorks software which can configure the balance points and hydrodynamics of the ROV, with simulations in ROV device. Meanwhile, the right and left parts of the ROV uses acrylic material with of $5 \mathrm{~mm}$ at thickness to protect the open area of the ROV.

\subsection{Component Design}

In designing ROV Lelebot 1.0, some components used 3-dimensional printing. Motorcycle support, safety motors, and propellers are printed in 3D printing in Figures 4-6. The advantage of using 3D printing components is the ease of customizing designs in accordance with the design of ROV. In addition, the result of printing with filament material is waterproof so that it is not necessary to cover the components.

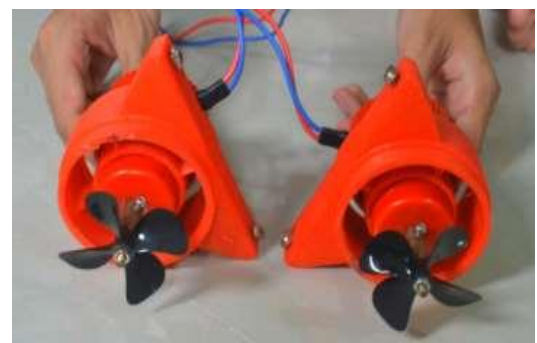

Figure 4. 3D Printing Cover Bilge Pump

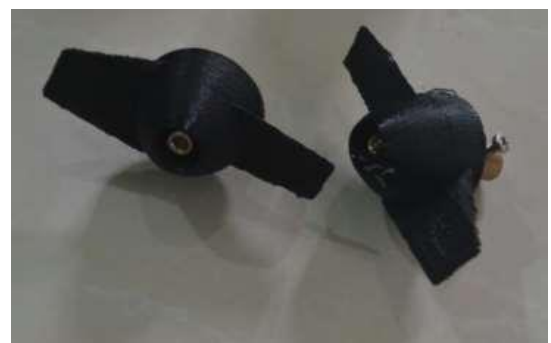

Figure 5. 3D Printing Propeller

\subsection{Electronic Protective Design}

Electronic Enclosure in ROV Lelebot 1.0 is an electronic instrument safety mechanism which is one of the safety protocols in the ROV. The electronic enclosure design used is made of plastic composition of $15 \times 15 \mathrm{~cm}$ which is placed in the central of ROV which contains a micro-controller and cable port in Figure 7.

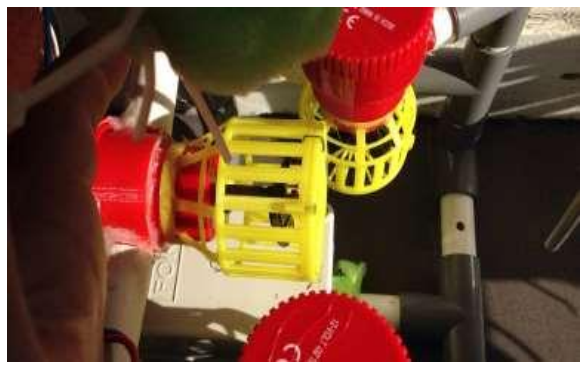

Figure 6. 3D Printing Propeller Protector

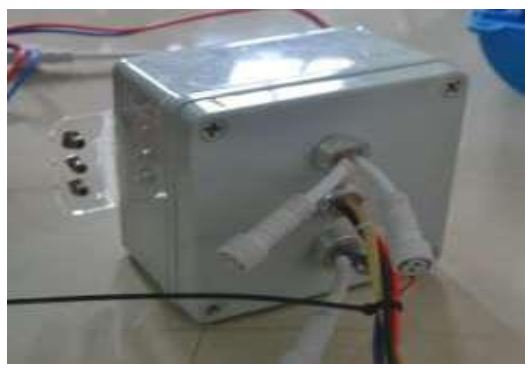

Figure 7. Electronic Enclosure

\subsection{Connector Design}

The ROV Lelebot 1.0 uses AWM 2464 multi-conductor cable with 9 conductors of 24 AWG to send video signals and communication serial data. The power supply connector used by ROV is the Anderson powerpole connector linked by cable $4 \mathrm{~mm} 2$ (11 AWG), after doing some studies on cable thickness match to the effectiveness of ROV. When the cable is too thick, the cable will be heavy and disturbing, whereas if the cable is too thin, a voltage drop will occur because the current range is 22 Ampere and the resistor is too high. Based on a maximum standard of 25 Ampere, the ROV can use cable $4 \mathrm{~mm} 2$, and after its testing there was no problem in voltage or load reduction.

\subsection{Propulsion System Design}

In propulsion system, ROV Lelebot 1.0 uses 4 motors, 2 units are placed for vertical movement and 2 other units are used for horizontal movement. The motor used in the ROV is Bilge pump 1100GPH with a maximum forward push of $2.36 \mathrm{kgf}$ and a maximum back pressure of $1.85 \mathrm{kgf}$. In addition, the ROV motor is made along with the propeller as a driving instrument, so the propeller is designed clockwise and counterclockwise in pairs to fight torque and stabilize the ROV movement. Bilgepump 1100GPH as shown in Figure 8, and Thrust Vector ROV as shown in Figure 9. 


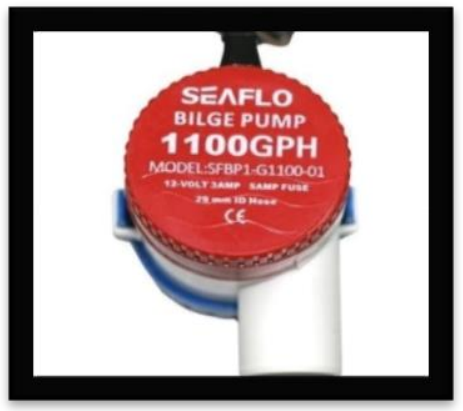

Figure 8. Bilgepump 1100GPH

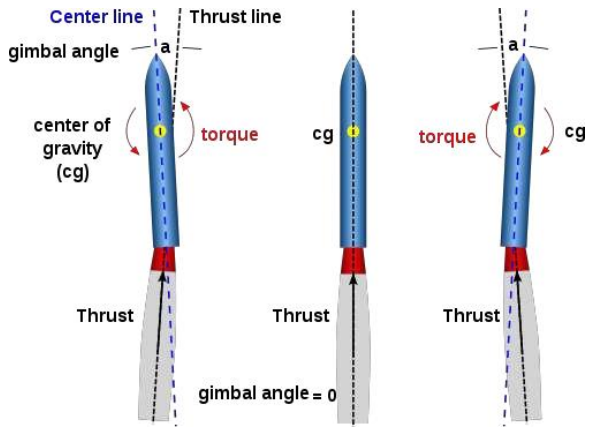

Figure 9. Thrust Vector ROV

\subsection{Gripper}

The gripper in the ROV Lelebot 1.0 uses 2 degrees of freedom, and consists of 1 servo which basically becomes the main function for clamping a material. For visualization, the ROV is equipped with 2 cameras that provide visual facing to the gripper and a straight view from the ROV.

\subsection{Camera}

In the visual system, the ROV Lelebot 1.0 is designed with 2 cameras placed in front of the ROV. The first visual faces straight so that the user (pilot) can get clear visuals to move the ROV maneuver, and the second visual is placed facing the gripper to give visuals to the main function of the instrument. Monitor and Camera as shown in Figure 10-11.

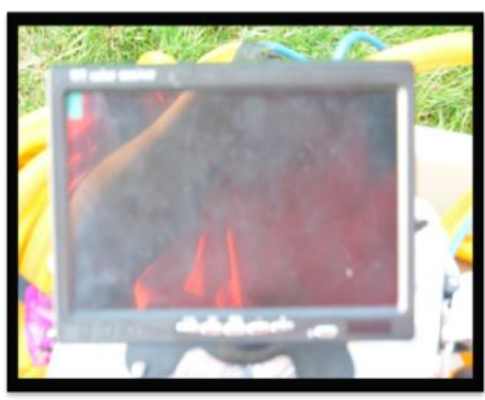

Figure 10. Monitor

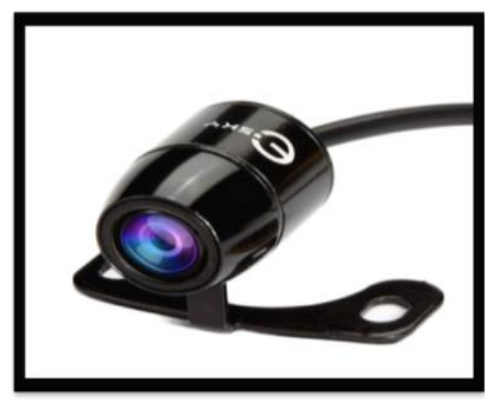

Figure 11. Camera

\subsection{Hardware and Controls}

The ROV Lelebot 1.0 is controlled by game controller (joystick). This remote control is controlled via a USB device connected to a laptop/PC, using the control box as an input variable. Communication from devices that use the Graphical User Interface (GUI) to control the ROV Lelebot 1.0, applies Visual Basic software, which functions as a device that connects the controller commands in RS232 to further control the Arduino Nano microcontroller in ROV Lelebot 1.0. Microcontroller is a device that receives and perform instructions from user [16]-[20] The microcontroller is programmed in C-Basic language. Arduino Nano uses 4 drivers to drive 4 motors of ROV Lelebot 1.0. Other input and output devices are servo motors for gripper and 2 camera controllers. All these inputs and outputs are installed into a custom Printed Circuit Board (PCB). As the further development of ROV design, ROV control can apply remotely through wireless [21], or the application of Internet of Thing design as control device. Lot constitutes a tool that can be used to control device from far distance [22]-[25].

\subsection{Software Design}

The software design of ROV Lelebot 1.0 uses C-Basic Language, with examples of source code shown in Figure 12. 


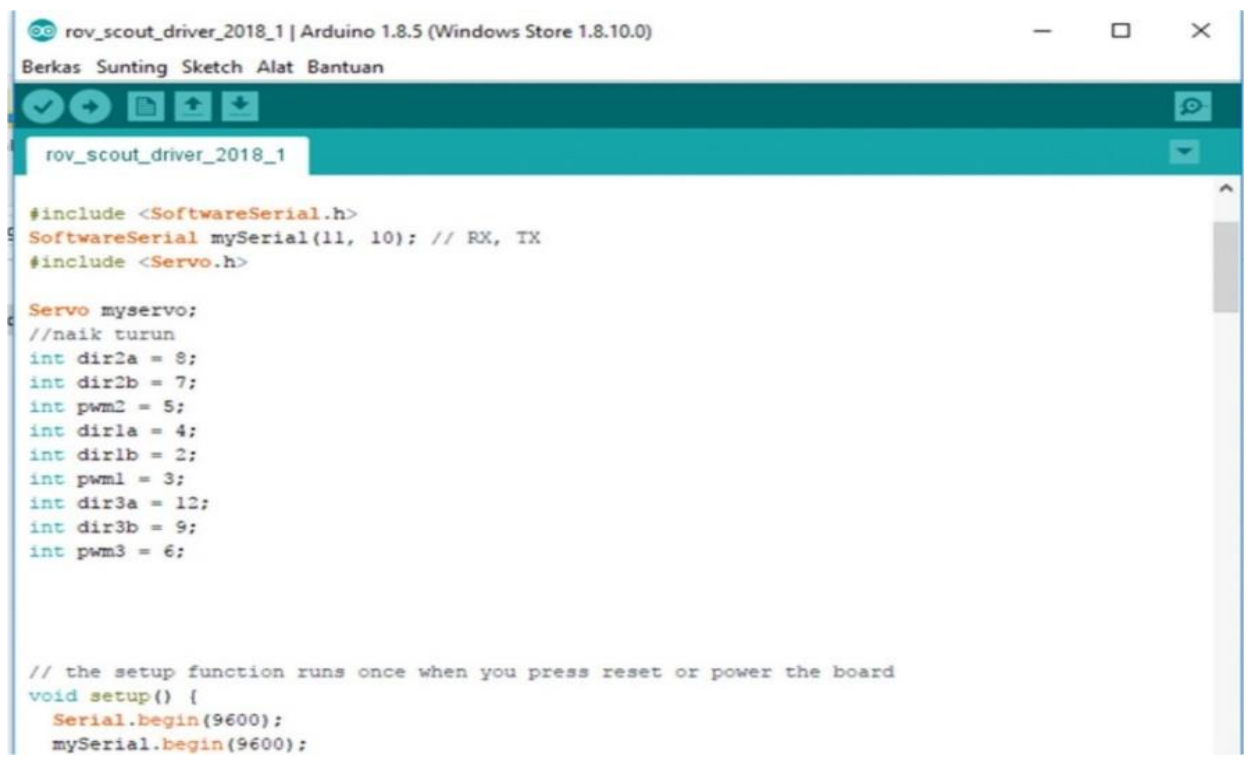

Figure 12. Programming with C-Basic

\subsection{Final Design}

In order to perform the philosophical base in the ROV assembly goals, the design of the ROV Lelebot 1.0 always has 3 considerations in its assembly, namely: safety ROV, safety pilot, safety environment. The assembly objective in this article is to produce ROV that can safely install seismograph and tidal turbine. The installation process of seismograph and tidal turbine should not be done conventionally because it has several risks, such as biohazard. In this principle, the ROV Lelebot 1.0 designed does not only avoids the risks of using conventional methods, but also does not make risks for the installation, pilot, or ROV environment itself. Final design of ROV Lilibot 1.0 as shown in Figure 13.

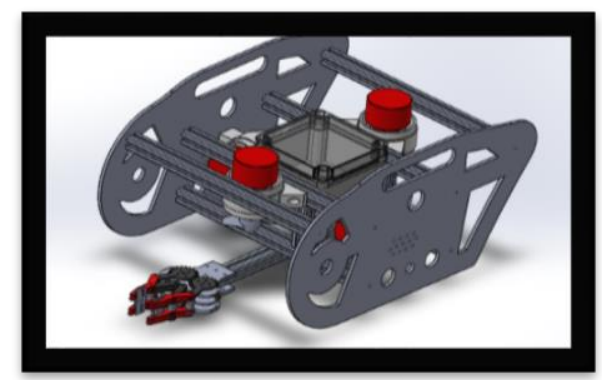

Figure 13. Final design of ROV Lilibot 1.0

\subsection{ROV Testing}

The designed ROV Lelebot 1.0 was tested through simulation on the activities of ASEAN level Marine Advance Technology Education (MATE 2018) at ITS Surabaya on 29 April 2018. The ROV designed was able to carry out a mission well in the installation of seismography at a depth of 2 meters under water, during 15 minutes in wavy water.

\section{CONCLUSION}

The ROV Lelebot 1.0 is designed to be able to carry out a good mission in installing tidal turbines and seismographs at the depth of 2 meters under the surface of water, during 15 minutes in wavy water. For further research, it is necessary to design an ROV that uses wireless remote control which is considered to be more efficient because the robot can move freely without cables. 


\section{REFERENCES}

[1] C. Slamet, A. Rahman, A. Sutedi, W. Darmalaksana, M. A. Ramdhani, and D. S. Maylawati, "Social Media-Based Identifier for Natural Disaster," IOP Conf. Ser. Mater. Sci. Eng., vol. 288, no. 1, p. 012039, 2018.

[2] R. Irvan, M. Taufiq, C. Slamet, R. Andrian, H. Aulawi, and M. A. Ramdhani, "Early Warning System in MobileBased Impacted Areas," Int. J. Eng. Technol., vol. 7, no. 3.4, pp. 118-121, 2018.

[3] M. I. Setiawan, H. Budiyanto, F. Kurniawan, S. W. Mudjanarko, and R. D. Nasihien, "2015 Poros Maritim Dunia dan Bencana Tsunami: Pengembangan Air Inflated Structure sebagai Fasilitas Tanggap Bencana," INA-Rxiv Papers, 2017.

[4] N. I. Rahmawati, B. J. Santosa, W. Setyonegoro, and B. Sunardi, "Pemodelan Tsunami di Sekitar Laut Banda dan Implikasi Inundasi di Area Terdampak,” J. SAINS DAN SENI POMITS, vol. 6, no. 2, pp. 2337-3520, 2017.

[5] W. H. W. Hassan, A. Z. Jidin, S. A. C. Aziz, and N. Rahim, "Flood disaster indicator of water level monitoring system,” Int. J. Electr. Comput. Eng., vol. 9, no. 3, pp. 1694-1699, 2019.

[6] N. N. Sari, "K-Affinity Propagation (K-AP) Clustering Untuk Klasifikasi Gempa Bumi: Studi Kasus Gempa Bumi di Indonesia Tahun 2017," Jogyakarta, 2017.

[7] Y. Jo and S. Lim, "Design and implementation of heterogeneous surface gateway for underwater acoustic sensor network," Int. J. Electr. Comput. Eng., vol. 9, no. 2, pp. 1226-1231, 2019.

[8] N. R. Ismail, M. Aliff, I. Yusof, and N. Samsiah, "Development of Remote Operated Vehicle (ROV) Control System Using Twincat at Main Control Pod (MCP)," in International Conference on Artificial Intelligence and Robotics for Industrial Applications (AIR 2018), 2018.

[9] M. I. Sani, S. Siregar, A. P. Kurniawan, and M. A. Irwan, "FIToplankton: Wireless Controlled Remotely-operated Underwater Vehicle (ROV) for Shallow Water Exploration," Int. J. Electr. Comput. Eng., vol. 8, no. 5, pp. 3325-3332, 2018.

[10] E. Mulyana, N. U. Adiningsih, and C. A. Fauzi, "Rancang Bangun Robot Bawah Air Menggunakan Sistem Ballast Berbasis ROV (Remotely Operated Vehicle) dengan Frekuensi 433 Mhz," J. Tekekomunikasi, Elektron. Komputasi, dan Kontrol, vol. 2, no. 2, pp. 126-137, 2016.

[11] M. A. H. Koli, E. D. Marindani, and A. Hartoyo, "Rancang Bangun Robot Bawah Air Mini ROV (Remotely Operated Vehicles) Berbasis Mikrokontroler ATMega16," J. Tek. Elektro Univ. Tanjungpura, vol. 2, no. 1, pp. 1-10, 2015.

[12] M. S. Gitakarma, K. U. Ariawan, and N. A. Wigraha, "Alat Bantu Survey Bawah Air menggunakan Amoba, Robot berbasis ROV,” J. Sains dan Teknol., vol. 3, no. 2, pp. 392-409, 2014.

[13] F. Nugraha, R. Pramana, and E. Prayetno, "Rancang Bangun ROV (Remotely Operated Vehicle) Berbasis Arduino Uno R3," Tanjungpinang, 2018.

[14] Sugiyono, "Metode Penelitian Pendidikan: Pendekatan Kuantitatif Kualitatif, dan R\&D". Bandung: Alfabetha, 2011.

[15] M. D. Gall, W. R. Borg, and J. P. Gall, "Educational research: An introduction". New York: Longman Publishing, 1996.

[16] A. Faroqi, M. A. Ramdhani, M. F. Amrillah, L. Kamelia, and E. Nuraeni, "Light Control and Watering System in Greenhouse for The Cultivation of Chrysanthemum Sp,” Indones. J. Electr. Eng. Comput. Sci., vol. 12, no. 3, pp. 950-957, 2018.

[17] A. Faroqi, A. Fitriadi, N. U. Adiningsih, and M. A. Ramdhani, "Automatic Door Control System Using SMS Gateway Base on Arduino Uno and Ultrasonic Sensor," Int. J. Eng. Technol., vol. 7, no. 3.4, pp. 122-126, 2018.

[18] M. H. Widarto, "Aplikasi Pengatur Lampu Lalu Lintas Berbasis Arduino Mega 2560 Menggunakan Light Dependent Resistor (LDR) dan Laser," Jakarta, 2014.

[19] A. Faroqi, M. A. Ramdhani, L. Kamelia, C. Hidayat, and A. Rofiq, “Automatic Water Clarity Monitoring and Filtration System Using Light Dependent Resistor Based on Arduino Uno," in 4th International Conference on Wireless and Telematics (ICWT 2018), 2018, pp. 1-4.

[20] N. M. Saad, A. R. Abdullah, N. S. M. Noor, N. A. Hamid, M. A. M. Syahmi, and N. M. Ali, "Automated medical surgical trolley," Int. J. Electr. Comput. Eng., vol. 9, no. 3, pp. 1822-1831, 2019.

[21] A. R. Darlis, A. Widura, and M. R. Andrian, "Bidirectional Underwater Visible Light Communication," Int. J. Electr. Comput. Eng., vol. 8, no. 6, pp. 5203-5214, 2018.

[22] W. Uriawan, W. B. Zulfikar, R. M. Sofa, and M. A. Ramdhani, "Internet of things for automatic garage doors using \{ESP 8266 module,” \{IOP\} Conf. Ser. Mater. Sci. Eng., vol. 434, p. 12057, Dec. 2018.

[23] A. K. Pasha, E. Mulyana, C. Hidayat, M. A. Ramdhani, O. T. Kurahman, and M. Adhipradana, "System Design of Controlling and Monitoring on Aquaponic Based on Internet of Things," in 4th International Conference on Wireless and Telematics (ICWT 2018), 2018, pp. 1-5.

[24] E. Mulyana, F. Abdurahim, M. A. Ramdhani, and O. T. Kurahman, "Analisis dan Perancangan Arsitektur Sistem Aplikasi Layanan Informasi Lokasi Berbasis IoT," in Prosiding-Seminar Nasional Teknik Elektro UIN Sunan Gunung Djati Bandung, 2019, pp. 243-252.

[25] N. Fajrin, I. Taufik, N. Ismail, L. Kamelia, and M. A. Ramdhani, "On the Design of Watering and Lighting Control Systems for Chrysanthemum Cultivation in Greenhouse Based on Internet of Things," IOP Conf. Ser. Mater. Sci. Eng., vol. 288, no. 1, p. 012105, 2018. 